\title{
E. S. BEESLY AND KARL MARX ${ }^{1}$
}

Edward Spencer Beesly was born in the village of Feckenham,
Worcestershire in I $83 \mathrm{I}$. His father was an evangelical minister, a man

1 The principal sources used in writing this article were:

a. The archives of the International Institute of Social History, Amsterdam (I.I.S.H.).

b. The archives of Le Musée d'Auguste Comte, Paris (M.A.C.).

c. A collection of some thirty letters and cards by Beesly to Marx, sent on micro-film from the Marx-Engels-Lenin Institute, Moscow (M.E.L.I.).

d. The George Howell Collection in the Bishopsgate Institute, London (B.I.).

e. "A Positivist Archive", being part of the Richard Congreve papers held in the British Museum. (British Museum Add. Mss. 45227/64). (P.A.B.M.).

f. The Webb (Trade Union) Collection, British Library of Political Science, London (W.T.U.C.).

I am indebted to the directors of these institutions for their generous cooperation. I am also indebted to the Sheffield University Publications Committee for making a grant from the research fund which enabled me to visit Le Musée d'Auguste Comte in Paris.

The titles and descriptions of other unpublished sources, such as the Home Office, the Gladstone, the Henry Solly, the University College, the London Trades Council and the Congreve (Wadham) collections are given in full in the text.

I found it convenient, when referring to the published letters of Marx and Engels, to cite one or other of the two English editions of their selected correspondence rather than the German or Russian collections. The first of these editions appeared under the title, Karl Marx and Frederick Engels, Selected Correspondence 1846-1 895, with Commentary and Notes; translated by Dona Torr, London 1934. (Abbrev.: Sel. Corr. Torr.) The second is Karl Marx and Frederick Engels: Selected Correspondence, Moscow and London 1956. (Abbrev.: Sel. Corr. 1956). Both editions contain numerous errors, but I generally preferred Dona Torr's to the more recent one.

I am indebted to Mr Chimen Abramsky and to Mr. J. E. Williams for reading the manuscript and making a number of critical suggestions.

I am also under a special obligation to Mr F. Kool, editorial secretary of this journal. He has done me the honour of making a detailed criticism of my work which has drawn attention to weaknesses and saved me from a number of errors. I am grateful to him for his patience as well as for his erudition.

However, I alone am responsible for such errors as may remain. Nor are those whose help I have the pleasure of acknowledging to be held in any way answerable for the 
of severe moral standards. He imposed upon his son an onerous system of academic and religious discipline, and in 1849 dispatched him to Wadham College, Oxford, which was at that time the stronghold of the evangelical party in the University.

The young Beesly had already been deeply impressed by the radicalism of Bright and Cobden and the continental revolutions of 1848.1 In the Union he distinguished himself as an effective exponent of Republicanism abroad, and of a brand of extra-parliamentary radicalism at home. ${ }^{2}$ At Wadham he met Frederic Harrison and J. H. Bridges and became, with them, one of the leading figures in an informal college society known to its detractors and members alike as "Mumbo-Jumbo". ${ }^{3}$ The members of this society were by no means all agreed on the great political and religious issues of the day, but they were all subject to the influence of Richard Congreve - the most popular and influential tutor at Oxford in the middle of the nineteenth century. 4

Although Congreve never mentioned Comte's name while Beesly was at Oxford, he had already fallen under the spell of the French philosopher. Positivism, which was at once a theory of knowledge, a philosophy of history, and a programme for social and political reconstruction, exercised a growing attraction for him. The classification of the sciences and "the law of the three stages" provided the basis for a much more satisfactory syllabus than anything to be found in the University of Oxford; Comte's concept of Humanity suggested the terms in which the conflict between science and religion might be resolved; the Positive Polity, on which Comte was still at work, held out the prospect of reconciling Order and Progress, of escape from the Scylla of Reaction and the Charybdis of Revolution. The master idea was to effect the final realisation of positive method and knowledge by the creation of the new science of sociology which, once established,

argument of this article. Indeed, with the possible exception of $\mathrm{Mr}$ Williams, they dissent from it more or less strongly.

1 Beesly, E. S., Strike Riots, in: The Positivist Review, Oct. I9I I.

2 Morrah, H. A., History of the Oxford Union Society, London 1923, pp. I 25 and I 53 ; Harrison, F., Edward Spencer Beesly, in: The Positivist Review, Aug. I9I 5.

${ }^{3}$ Harrison, F. Autobiographic Memoirs, Vol. I, London I9I I, p. 87.

- Frederic Harrison, 1831-1924. See Autobiographic Memoirs, 2 vols., 1911. Also Harrison, A., Frederic Harrison - Thoughts and Memories, r926. - J. H. Bridges. See Liveing, S., A Nincteenth Century Teacher, 1926. There are also two biographies of Bridges which were printed for private circulation: Bridges, M. A., Recollections of J. H. Bridges M. B., 1908, and Torlesse, F. H., Some Account of J. H. Bridges and his Family, I91 2. - R. Congreve, 1818-1899. Although there is a large collection of autobiographical and other notes in the Congreve Collection at Wadham and in the British Museum (A Positivist Archive: Add. Mss. 45227-64), there is no "Life" and it is necessary to consult the Dictionary of National Biography (D.N.B.). 
would indicate the proper object of religious sentiment, and afford a basis for secure and demonstrably correct moral judgments. ${ }^{1}$

It was not long before Beesly, Harrison and Bridges discovered the source of Congreve's inspiration. After they left the University they devoted much time to studying Positivism, and one by one they came to the conclusion that it was the answer to the demands of their age.

After spending a few years as an assistant master at Marlborough College, Beesly was, in I 859, appointed Principal of University College Hall, London. A year later he was appointed to the Chair of History in the College. Congreve had boldly resigned his Oxford appointments and was preaching Positivism in the metropolis. Harrison and Bridges were also in London. Soon the old association was resumed and the Positivists began to make themselves felt in public affairs.

This reunion of i 899 coincided with the outbreak of the great strike and lock-out in the London Building Trades. The workers demanded the nine-hour day, the masters retaliated by presenting them with "the document". Under a variety of forms the conflict continued for about two years. ${ }^{2}$ Beesly and the other Positivists lost no time in identifying themselves with the cause of the bricklayers, carpenters, painters and masons of London. ${ }^{3}$

From the beginning, all Beesly's work in the Labour Movement was based upon Auguste Comte's conception of the nature of the proletariat and its "historical destiny" in relation to the new religion. He was opposed to competition, which was the source of crises of overproduction. He was opposed to that "vulgar" political economy which extolled such competition. He believed that the welfare of "la classe la plus nombreuse et la plus pauvre" was the criterion by which to judge all public action. He regarded social rather than political movements as the ones best calculated to improve the conditions of the wage-earners. He held that capital tended to become concentrated in fewer and fewer hands and that consequently society would soon be exhaustively divided into two classes: the bourgeoisie and the proletariat; workmen and non-workmen. The antagonism between these two classes was becoming increasingly pronounced. The conditions of life of the proletariat made for its moral superiority over the capitalists; among workmen one found a greater prevalence of altruism

1 The work in which the unity of Comte's doctrine is made most apparent, as well as being expounded with something like brevity is "Discourse on the Positive Spirit", 1844, English translation by Beesly, I903.

2 Postgate, R., The Builders' History, London 1923, pp. 170-1 77.

3 Webb, S. and B., History of Trades Unionism, London I 894, P. 247. 
and - since their minds were not cluttered up with a lot of crotchets which passed for knowledge and learning - they were able to take a larger as well as a nobler view of the great issues of public policy. Wealth was social in its origins and even if it was individually appropriated, it ought to be directed in socially beneficial ways. To this end trade unionism could be of some service, but ultimately only an organised public opinion which was scientifically directed and guided by a Positivist priesthood could moralise the capitalist and satisfy the rightful claim of workmen to secure employment, education, and a tolerable standard of life. Such a priesthood could only exert authority once it had secured, as it would do, the support of the two great oppressed sections of modern society, the workmen and the women.

In the new society, political power was to be organised within much smaller units, and would be exercised directly by moralised bankers and capitalists, instead of being exercised indirectly, as it was in Parliamentary regimes, by immoral bankers and capitalists. These great changes were not to be established over-night; in the transitional period it might be necessary to establish a proletarian dictatorship in which some distinguished workman exercised absolute power. Nor would this new society be established simultaneously throughout the world; it was destined to arise first in the "five great countries of the West", of which France was the foremost representative. This unequal development of Positivism was related to the unequal development of the proletariat, of which the French was the most advanced. In particular, the proletarians of Paris compared most favourably with those found elsewhere, especially the English, who were backward and marked down for Communism. ${ }^{1}$

The proletariat was not to be won for Positivism by mere proselytising. "Philosophers", declared Comte, "will never be able to manage the working class as they please, as some unprincipled agitators have imagined, but when they exercise their authority rightly, whether it be in the cause of Order or that of Progress, they will have great power over their passions and conduct. Such influence can only spring from long-cherished feelings of gratitude and trust due not merely to presumed capacity, but to service actually rendered."2

It was this doctrine which brought Beesly to the mass meeting which the building workers held in Hyde Park, and which explains the approval with which he received the remark of one speaker that "if

1 The most convenient introduction to Comte's teachings on the Labour Movement is: Auguste Comte, Le Prolétariat dans la Société Moderne, Textes Choisis, avec une introduction de R. Paula Lopes, Paris 1946.

2 Comte, A., The General View of Positivism, London 1865, Chap. III. 
political economy is against the workman, then the workmen will be against political economy". ${ }^{1}$ It was as disciples of Comte that Harrison and he worked in conjunction with the Christian Socialists to get the strikers' case plainly stated in the press. This work was done most effectively and in the course of doing it Beesly soon came to be on close terms with George Odger, Robert Applegarth, Edwin Coulson, George Howell, William Allan and other men who came to dominate the newly established London Trades Council, and who were the exponents of the "new model" unionism. The formative state of labour organisation in the early sixties provided favourable opportunities for being of service and exerting influence long after the builders' struggle had ended. Beesly maintained a continuous association with many of the most important union leaders. In particular, he was a much respected friend and confidant of Odger ${ }^{2}$ and Applegarth, ${ }^{3}$ eventually becoming the first honorary member of the Amalgamated Society of Carpenters and Joiners. He was an important contributor to the Bee-Hive, the weekly newspaper managed by George Potter, which was originally intended to serve as organ of the Trades Council. Nor was it only those unions which had their offices in London which came to know and respect him; he received tributes not only from the bookbinders and bricklayers, ${ }^{4}$ but from the National Association of Miners which, shortly after its foundation in 1863 , made him one of its official advisers. ${ }^{5}$

The policies which Beesly pressed upon the labour leaders during and after the builders' strike led to his being chosen to preside over the historic meeting held in St. Martin's Hall, Long Acre, on 28th. September 1864, at which the International Working Men's Association was established. The choice was appropriate on account both of his eminence in the labour movement, and because of the direction of his activities.

As early as 1859 the Positivists had been considering how the building strike might be used to promote a closer union between the French

1 Compare E. S. Beesly in the Weekly Dispatch, 8 July 1877, with Reynolds News, report of Hyde Park meeting, 7 Aug. 1859.

2 Beesly, E. S., George Odger, in: Weekly Dispatch, 18 March 1877 . (For further light on Odger's relation to Beesly and Positivism see R. Congreve, Diary, 22 Sept. 187 O [P.A.B.M. Vol. XXV, 4526I] and Davies, C. M., Heterodox London, London i 874, Vol. II, p. 242).

${ }^{3}$ Commemoration of Edward Spencer Beesly. Notes of Addresses by Mr. Applegarth and Mr. Herbert Burrows, in: The Positivist Review, Nov. I9I5; and also Amalgamated Society of Carpenters and Joiners, Monthly Report: Address by Applegarth, July 1869. 4 Bookbinders Trade Circular, 21 Nov. 186I; and Operative Bricklayers' Trade Circular, Nov. 1862.

- A Deputation of Miners at the Marquis Townshend's, in: The Miner, 2 Jan. I864. 
and the British proletariats. ${ }^{1}$ The American Positivist, Edger, was thinking in terms of "A Conference of true Proletarians", which might be helpful in the "transition period". ${ }^{2}$ They were in touch with the leading French proletarian Positivist, Fabien Magnin, with the object of securing some expression of sympathy for the strikers. It would help in bringing about a "rapprochement between the English and French proletariats, through Positivist intervention, and seemingly might have important results". ${ }^{3}$ Congreve and Magnin did, in fact, arrange something of the sort, ${ }^{4}$ and from that time forward the French worker was kept in continuous correspondence with George Odger and also with Eugène Dupont, an émigré musical instrument maker, resident in London. ${ }^{5}$ (Odger and Dupont subsequently became members of the General Council of the International, while Magnin, after consulting his English co-religionists about the character of the new Association, formed a section known as the Proletarian Positivists of Paris.) ${ }^{6}$

Throughout I86I and 1862 the Minutes of the London Trades council record the pressure which Beesly, Harrison and Congreve were bringing to bear so as to induce the fledgling labour leaders to

1 Winstanley, J. to P. Laffitte, io Nov. I859 (M.A.C.).

${ }^{2}$ Winstanley, J. to P. Laffitte, 8 Dec. 1859 (M.A.C.).

3 Winstanley, J. to F. Magnin, Is July I 86r (M.A.C.).

4 Magnin, F., Lettre sur la grève des ouvriers du bâtiment, Paris I 86r, pp. I-16.

${ }^{5}$ Kun, S., Notice sur la vie et l'oeuvre de Fabien Magnin, being the introduction to: Etudes Sociales par Fabien Magnin, Paris I 91 3, p. xxvi.

- Magnin, in an undated letter to an English co-religionist reported that he had been studying the reports of the delegates to the London exhibition, with the object of discovering the schemes and systems of thought which had Paris in a ferment. He declared that these reports were of great length (888 pages) and showed that the workers were all bent on ending the precarious and degraded condition of labour, most of them looking to co-operative production on an industrial level for a solution. "They fail to see that their plans are not compatible with the progress and liberty to which they profess their attachment." Towards the end of $\mathrm{I} 864$ he wrote to this correspondent (probably Beesly) again: "For some time I have received frequent invitations to enter into relations with it [the I.W.M.A.], but as you can see for yourself, their programme is so vague, so indeterminate, that I considered that I ought to take your advice before entering into relations with it." Finally, in a letter dated 27 Caesar 77 in the Positivist calendar i.e. 19 May I 865, Magnin writes: "Now I must thank you for your two good letters.... M. Fibourg of the I.W.M.A. presided at a discussion here. He said that the I.W.M.A. had no goal, but was simply a means. But why, I asked him, can you not assign a precise goal to a socialist movement? Because, he replied, social science has still to be created." Magnin went on to explain that this opened the way to Positivist propaganda and "many of those present were strongly impressed by the incident, some of them have already started to study Positivism." (Magnin's copies of his letters, Magnin collection, M.A.C. Paris.) - It may be that it was not until the late sixties that the Parisian Proletarian Positivists formed a section of the International. Members of the General Council itself seemed uncertain about the precise date of their affiliation. (See p. 54.) 
go in for political action and to establish contact with their French and Italian brothers. ${ }^{1}$ Their efforts were not at first conspicuously successful. The workers were understandably preoccupied with the problem of the internal organisation of their newly established unions. But apart from this consideration, the leaders of the "new model" were inclined to be insular and cautious to a fault. Beesly, who defended these organisations and their leaders against the attacks of George Potter and other opponents and detractors, ${ }^{2}$ was well aware of these "weaknesses" and continually tried to correct them. ${ }^{3}$ He regarded it as a great merit of English labour organisation that it should be primarily of an industrial and social character, but this could never be held to justify indifference to political or international issues.

However, by the end of 1862 a great international issue, the Civil War in America, had come to impinge with such effect upon the material conditions and political prospects of the British workmen that it was impossible for them to withhold judgement on the conduct of their own government or that of the combatants themselves. Beesly threw himself into the task of organising working-class support for the North with "passionate energy". 4 The task was a much more difficult one than the generally received account of how British workmen responded to the Civil War would suggest. There were influential labour leaders, advisers and journals which were hostile to the Northern States. It was only with great difficulty, after what Henry Adams described to the State Department as "patient efforts", that Beesly was able to persuade some of the London trade union leaders to organise a pro-Lincoln demonstration in St. James' Hall with John Bright in the chair. ${ }^{5}$ The meeting was the most memorable of all those held in support of the North. It was widely referred to as providing conclusive evidence as to where working-class sympathies lay; it was of decisive value in persuading trade union leaders of the value of

1 Minute Book of the London Trades Council, I7 Dec. 186x (Beesly on the need for political action); 20 May I 862 (Harrison on links with Italian workmen); Annual Report of 1862 (Congreve on need for links with French). (Minutes examined when offices of Council were in Great Ormond St, London.)

${ }^{2}$ See, for example, Beesly's three letters on the London Trades Council and Delegate Representation, in: The Bee-Hive, 2 Aug., 23 and 30 Sept. 1865.

${ }^{3}$ See, for example, Beesly, Public Education, in: The Commonwealth, I Sept. r866. For the general tenor of Positivist criticism see Harrison, The Good and Evil of Trades Unionism, in: The Fortnightly Review, Dec. I 866.

4 Beesly, E. S., Letter on America in: The Times, 9 Febr. 1872.

5 Glicksberg, C. I., Henry Adams Reports on a Trades Union Meeting, in: The New England Quarterly, Vol. XV (1942). 
political action, and it enabled them to score a triumph at the expense of George Potter, who was badly compromised by his association with the Confederate sympathiser and first editor of the Bee-Hive, George Troup. ${ }^{1}$

Beesly not only organised the St. James' Hall meeting, but was one of the principal speakers. His theme was that "the cause of labour is one, all over the world." If his argument served the cause of Lincoln and the North, it also indicated in the clearest terms the need for an organisation having the objectives which were to become the declared policy of the International. The American question, Beesly argued, must be looked at, as must every other question, by its bearing upon the interests of Labour. "Political economists tell us that labour is a commodity and, like other commodities, if it is very cheap in one place it will have a tendency in the long run to sink in value in other places also. It is not our interest that labour should be cheap here or anywhere else, much less that it should be absolutely unpaid... Now there may be some who may feel a little shocked at the idea of being classed with slaves, under the general term of labourers. They may feel loth to believe that their interests are the same, that they are fellow soldiers in the same cause, that the struggle over there is but another version of the struggle with which you are but too familiar here. And yet I think that the conception of the solidarity of labour is one which must have dawned on many of you of late years. I am persuaded that you have thought of the workingmen of France, for instance, as bound to you by sympathies and interests which overlap material and geographical demarcations."

Beesly then went on to arouse the class instincts of the "vast assemblage" against the upper classes - the persons who, forgetful of common prudence and decency, supported the slaveowners because they were "gentlemen". "They were passing the word round to stand by their order. Well, you stand by yours." The ruling class regarded all workmen as dangerous, people who had to be schemed against, deprived of the franchise, kept down. But let them "shut the door of the House of Commons in your face and value themselves on their cleverness. But when there is need you know how to make your voice heard. You would sweep away, like so many cobwebs, were it

1 For an account of the nature and origins of Southern sympathies in the Labour Movement, and of Beesly's activities during this period see my article, British Labour and the Confederacy, in: International Review of Social History, Vol. II (I957), Part I. For critical discussion of this article, see the editorial comment in the Bulletin of the British Association for American Studies, No. 4. 
necessary, the flimsy constitutional handcuffs in which they think they have you fast." 1

Although Karl Marx did not organise the great meeting in St. James' Hall, he was present. He sent Engels an enthusiastic description of the proceedings, in the course of which he praised the working-class speakers, and acknowledged that even old John Bright "looked quite like an Independent". ${ }^{2}$ Since he makes no mention of Beesly - whose speech would obviously have appealed to him immensely - one must presume that he left before the end of the meeting.

The American struggle was the first of three great questions of international policy which helped to prepare the way for the foundation of the I.W.M.A. The Polish and Italian questions were scarcely less important, and in both these matters Beesly helped to arouse working-class interest and support.

At this time Beesly was on friendly terms with James Stansfeld M. P., and moved among the circle of English radicals who were inspired by the spirit and the exploits of the revolutionary republican and nationalist movements on the continent. It was through Stansfeld that Beesly met Mazzini, who made a profound impression upcin him. ${ }^{3}$ When Garibaldi came to England in 1864 the Positivists encouraged all popular manifestations of support for him. ${ }^{4}$

A month after the St. James' Hall meeting in support of Lincoln, Beesly took Stansfeld's place as the chairman of a trade union demonstration in support of the Poles. At this meeting Beesly reiterated arguments which he had advanced in the pages of the Bee-Hive: the liberation of Poland required a Franco-British entente. The British ruling class feared French ideas, but the workers had no reason to do this. They had more in common with the French workers than they had with some classes of Englishmen, and they ought to join with them as the promoters of the liberties of their own and other countries. ${ }^{5}$

Harrison reinforced his friend in the pages of the Bee-Hive. Lord Palmerston had to be taught by the British workers that they were tired of his trickiness, "That they will not see the blood, wealth and honour of their country sacrificed to fill the pockets of some few merchants and manufacturers, and that before he enters upon a war

1 Great Meeting of Trade Unionists: Negro Emancipation. Professor Beesly's Speech, in: The Bee-Hive, 28 March 1863.

${ }^{2}$ Marx to Engels, 9 April I 863. Sel. Corr. Torr.

${ }^{3}$ Beesly, E. S., Mazzini and the French Plot, in: The Bee-Hive, s March 1864.

4 Harrison, F., The Departure of Garibaldi, in: The Bee-Hive, 21 May 1864.

5 The Independence of Poland: Great Demonstration by members of Trade Societies.

Report of the speech of the chairman, E. S. Beesly, in: The Bee-Hive, 2 May 1863. 
for the extension of British commerce in Asia, we shall take care of British honour and interest in Europe by resorting to arms - since arms alone will succeed - to secure a noble people to its place amongst the nations of the West." 1

It is partly in the context of this incessant propaganda for an understanding with France, and in the first instance with French workers, that the visit of a deputation of French workers to a great pro-Polish gathering in St. James' Hall must be considered. ${ }^{2}$ It will be recalled that it was the visit of this deputation in July I 863 which directly prepared the way for the founding of the International in the following year. After the Frenchmen had gone home, a committee of English trade unionists had been formed with the purpose of drawing up a fraternal address. This had been done by George Odger and translated by Beesly. This resulted in the French sending a further deputation with a reply to that address. The formal object of the famous meeting in St. Martin's Hall on September 28th. I 864, over which Beesly presided, was to receive this deputation and hear its reply. ${ }^{3}$

Enough has been said to show how Beesly came to chair the inaugural meeting of the International. It is clear that no account of the origins of that Association can be considered to be adequate if it neglects the preparatory work performed by the Positivists. Indeed, Beesly had a great deal more to do with the immediate business of founding the I.W.M.A. than had Karl Marx who was a "mute figure in [sic] the platform" and only concerned himself with the organisation on being satisfied that "real 'powers' were involved". ${ }^{4}$ The description, given by Engels, Lenin and others, of Marx as the "founder" of the International, is only correct if it is understood to apply to the post-natal period of its history. He was largely responsible for shaping its character, but he did not call it into being.

Although there has been no serious assesment of the work done by the Positivists in preparing the ground for the rise of the International, it should perhaps be noted that there was one contemporary of Beesly and Marx who was prepared to make extravagant claims for Comte, whose system he discovered to be "the power initiating the movement". P. H. Bagenal in an article on "The International and its Influence on English Politics" which appeared in vol. 2 of the National Review (September-February I 883-4), stated that "Comteism, it is

1 Harrison, F., Poland, in: The Bee-Hive, 27 June 1863.

2 Great Polish Demonstration at St. James' Hall, in: The Bee-Hive, 25 July I $86_{3}$.

a Report of the International Meeting in St. Martin's Hall, The Bee-Hive; report reprinted in: The Founding of the First International, editor, L. E. Mins, New York 1937, pp. I-17.

- Marx to Engels, 4 Nov. 1864 . Sel. Corr. Torr. 
alleged by those who know, furnished the framework of an international alliance between working men, and the origin and growth of the International Association is declared to be a logical conclusion". Unfortunately, Bagenal did not disclose the identity of his informants, nor did he reveal any evidence in support of their assertions.

After speaking at St. Martin's Hall about the contrasting methods by which Frenchmen and Englishmen sought to secure the rights of Labour and having denounced the predatory policies of governments (particularly the English Government), Beesly had little more to do directly with the new body. He respectfully declined the honour of becoming a member of the General Council, ${ }^{1}$ no doubt for much the same reasons as he declined offers of editorial control of workers' papers, and invitations to join, or assume leading positions in, such bodies as the Reform League and the Labour Representation League. The Positivists, in general, shrank from positions in which they would have to exercise power, and persuaded themselves that their influence over working-class opinion would be all the greater if they abstained from assuming such responsibilities.

\section{II}

The fact that Beesly did not join the International, did not eventually prevent his becoming well-acquainted with Marx, and working with him on friendly terms. On the contrary, it may plausibly be regarded as a condition - albeit a negative one - which favoured their collaboration. Beesly would have got in Marx' way if he had been on the General Council. There was a sufficient supply of issues on which they were opposed to have made conflict between them unavoidable, had Beesly been President of the International (as a workingmen's society in New Zealand imagined he was), ${ }^{2}$ or had the English Positivists formed their own section instead of merely serving as intermediaries between their co-religionists in Paris and the General Council. As it was, Beesly was able to observe with a characteristic touch of shrewd humour, that "Dr. Marx and I were always good friends; to the end of his life I had a great esteem and regard for him: and I am sure that he considered me to be a well-meaning person - which was more than he was willing to allow with regard to most people who differed with him." 3

1 Minutes of the General Council of the I.W.M.A., 8 Nor. 1864 (I.I.S.H.).

2 Ibid., 9 May 187 r.

${ }^{3}$ Beesly, E. S., letter in Christian Socialist, March I 884. (Also to same effect:) Beesly, E. S. to Miss (Eleanor) Marx, 24 March 1883 . (M.E.L.I.) 
The two men first became well acquainted with each other through the intermediacy of Paul Lafargue, ${ }^{1}$ who became Marx' son-in-law, and who had been a Positivist in his youth. ${ }^{2}$ Prior to I 869 there is little to suggest that their association was a close one, ${ }^{3}$ but there were a number of matters which tended to draw them together.

First, there was a growing identity of view on the immediate political tasks and future of the working class. Up till about 1863 , Beesly had been all in favour of a political alliance under the leadership of John Bright, between the radical manufacturers and the workmen. ${ }^{4}$ He continued throughout the Reform agitation to recommend Bright to the working class, and to do what he could to consolidate and strengthen the alliance which he himself had done so much to bring about. ${ }^{5} \mathrm{He}$ always was inclined to treat the great Radical as a useful approximation to Comte's "Captain of Industry", but he became more and more convinced that Bright had to be regarded as the exemplar, rather than the representative, of the manufacturing capitalists. With Harrison and Bridges, he was convinced that the antagonism between the middle and working classes was far more profound than that between the reformers as a whole and the ruling oligarchy. ${ }^{6}$ Consequently, from a position which was initially quite opposed to that taken up by Marx, Beesly moved, in practice, towards very much the same position. On no account, he argued, must the workmen allow themselves to be hoodwinked by middle-class slogans and promises; they must never lose sight of the fact that they want the suffrage as a useful instrument for the promotion of their class interests, and not because of a lot of vague, metaphysical chatter about "natural rights". It was their duty to themselves to organise mass pressure on Parliament, even if this involved taking the responsibility for the preservation of law and order into their own hands. Indeed, he publicly called - at the most critical moment in the summer of 1866 , when trade depression had brought a new edge to the agitation - for the formation of a body of " 5,000 volunteer police, or Reform constables, distinguished by a badge, acting under serjeants, inspectors and superintendents, and provided with useful sticks." He added, "I, for one, shall be ready to serve as a Reform Constable." 7 It was precisely

${ }^{1}$ Marx to Engels, 16 May I 868, Marx/Engels Gesamtausgabe.

2 "Paul Lafargue", Great Soviet Encyclopaedia, Moscow.

${ }^{3}$ See below p. 42.

4 Beesly, E. S., Letter in Operative Bricklayers' Friendly Society Trade Circular, Dec. I 862.

5 Beesly, E. S., to George Howell, 15 March 1866 . (B.I.) Reform meeting in Uxbridge. Speech by Beesly, Buckinghamshire Advertiser and Uxbridge Journal, 3 I March 1866.

- Reform meeting in St. Martin's Hall, speech by Beesly, in: The Bee-Hive, 14 Apr. 1866.

7 Beesly, E. S., Reform Constables, in: The Bee-Hive, 25 Nov. 1866. 
this sort of proposal which John Bright declared would "place the peace of the country on a soil hot with volcanic fire." 1

Marx and Beesly were united in centring their attention upon the Reform League, and in deploring the disruptive and adventurist policy pursued by Potter through the Bee-Hive and his London Working Men's Association. Beesly had for a time broken with the Bee-Hive over its American policy ; ${ }^{2}$ Marx had conspired, unsuccessfully to capture control of the paper. ${ }^{3}$ In 1865 they both began to try to develop a new journal as a rival organ. ${ }^{4}$ It was The Miner and Workman's Advocate, subsequently renamed The Commonwealth. They - and the leaders of the Junta who were associated with them in this project - were not alone however in their plans for the development of a new journal of working-class opinion. A number of radical manufacturers and members of the middle-class Reform Union had their eye on the paper and soon secured an important measure of control over it. ${ }^{5}$ These manufacturers, in the person of S. C. Kell of Bradford, used the columns of the paper to lay about both Positivists and Marxists (Ernest Jones was a contributor) as instigators of class hatred and enemies of Reform. ${ }^{6}$ The polemic raged on from week to week and took up so much space that there was no room to print communications from Marx himself.? Utterly disgusted with the whole business, Marx learned that Beesly and Harrison were considering an open break with the Commonwealth, which would be marked by a public statement that they were doing so because Kell and Co. held the purse-strings. He informed Engels, who was a contributor, that the farce would have to be brought to an end. He would propose that they sold out their interest to Kell and had no more to do with the paper. ${ }^{8}$

In the end the canny manufacturers appear to have hesitated to acquire an enterprise that was so perilously near the rocks. 'They retired from the scene, leaving Marx' pupil, Eccarius, to preside over a venture that was thoroughly moribund.

1 John Bright to Charles Villiers, Nov, r 866. Cited by Trevelyan, G. M., Life of John Bright, p. 364 .

2 Beesly, E. S., The Colonies and the States, in: The Bee-Hive, I March I 864.

${ }^{3}$ Marx to Engels, 9 May I 86, and 3 I July I 865. Marx/Engels Gesamtausgabe.

4 Marx to Engels, 3 I July I 865 . (Ibid.)

5 Articles of Association, list of shareholders, The Industrial Newspaper Company. Records Office, London.

- Kell, S. C., An English Radical's Protest against the Political Doctrines of the Comtists, in: The Commonwealth, 12, 19, 26 May 1866.

7 Editorial note to Karl Marx in: The Commonwealth, I May I 866.

8 Marx to Engels, 9 June 1866 . Marx/Engels Gesamtausgabe. 
After the passage of the Reform Act, Beesly once more came into collision with Kell and under circumstances which provide a remarkable illustration of the practical identity between his approach to the political tasks of the working class and that of Marx.

In August 1867 Beesly visited his friend Bridges in Bradford, the home of Sam Kell. He persuaded a group of leading workmen there that they ought to work for a programme of industrial and social reforms rather than line themselves up behind the middle-class radicals who were concentrating on merely political measures. Beesly was accordingly asked to draft such a programme." He headed it "The General Election of 1869 : programme for Trade Unions." 2 It was explicitly intended to separate the workmen from the middle-class radicals and to organise them into an independent political force in the impending general election. There were six main points. The first three concerned changes in the law relating to trade unions and strikes; the remainder dealt with "a large and progressive extension of the factory acts; a reduction in indirect taxation to be matched by cuts in military expenditure and a property tax; a system of primary education - national, secular and compulsory". No-one, under any circumstances, was to receive the working-class vote who did not pledge himself to all or most of this programme, and plans were outlined for the selection and return of working-class representatives to Parliament.

Beesly cheerfully told Congreve that this was going to break Sam Kell's heart when he heard of it, and subsequently observed that "there will be little harmony between Bright and us henceforth, I fear." ${ }^{3}$ There is no evidence that Karl Marx knew of this project, but, if he did, he can hardly have failed to have approved of it in all its essentials. The last three planks in Beesly's platform had appeared in the programme of the Geneva Congress of the I.W.M.A. in 1866. Further, Beesly's programme was nothing less than an anticipation of that concept of independent labour politics propounded by Engels in $188 \mathrm{I}$ and by Hardie and Champion still later, ${ }^{4}$ the sole substantial difference being that Beesly did not expect or desire the new party to become socialist, even though it would see "social questions" and "the control of capital" as decisive. It should be remembered that the

1 Beesly E. S., to Congreve, 28 Aug. I 867 (P.A. B.M.).

2 "The General Election of 1869 : Programme for Trade Unions." Then, in Beesly's hand, "written by E. S. Beesly". (W.T.U.C., Section B. Vol. CXX Itcm 4I.)

3 Beesly to Congreve, 20 Aug. I 867. (P.A. B.M.) For the clash between Kell on the one hand and Beesly and Bridges on the other, see twelve letters in the Bradford Review, between 3 I Aug. and 28 Dec. I 867.

- Engels, F., in: Labour Standard, 7 May to 6 Aug. I881. See also Pelling, H., The Origins of the Labour Party 1880-1900, London 1954, particularly p. 75. 
programme advanced by Keir Hardie in 1888 was no more socialist than the one propounded by Beesly twenty years earlier. What these two programmes had in common and what distinguished them from those which found favour with "respectable" labour leaders was, first, that the question of electing labour representatives was treated as subordinate to the question of the independence of those representatives and the movement as a whole; second, - as a corollary of this it was insisted that labour questions should take precedence over all others; third, it was the support of the trade unions and the trade unionists which was regarded as decisive for the success of the "labour party". (Neither Beesly nor Hardie pursued this policy with perfect consistency.)

Apart from the political tasks and future of the working class, there were other questions of public policy upon which Beesly took a stand which was bound to impress Marx as being both correctand courageous.

For instance, there was the Irish question, to which Marx came to attach increasing importance as the sixties wore on. ${ }^{1}$ Even before he brought the problem of Fenianism and Irish nationalism before the General Council, the Positivists had made a great stir on the matter. On 22nd. March 1867, Beesly and his fellow Positivists (including Edward Truelove, who subsequently acted as publisher to the International) had drawn up a petition which - when Bright introduced it into the House of Commons - caused an unprecedented uproar. "I wish, Sir," said Bright, speaking in the Commons on 3 rd. May, "to present a petition which is signed by twelve or thirteen gentlemen, well-known, I believe, to many members of this House as men of first-class education and position.... The petitioners state that in the apparent hopelessness of a remedy for the evils which press on their country, honourable Irishmen, however mistaken, may feel justified in resorting to force (Oh! Oh!)." Amidst further interruptions and calls for order Bright went on to state what the petitioners "prayed"; namely, for revision of excessive sentences on the Fenian prisoners, for their separation from common criminals and exemption from degtading punishments. Finally - and this was what offended many Honourable and Gallant Members - the petitioners prayed that in view of the atrocities committed during 1798 , during the Indian Mutiny, and again during the suppression of the recent disturbances in Jamaica, special steps be taken to inculcate into the British army "strict adherence to the laws of fair and humane warfare"."

1 Marx to S. Meyer and A. Vogt, 9 April I870, in: Karl Marx and Frederick Engels on Britain, Moscow 1953 ; London I954.

${ }^{2}$ Parliamentary Report, in: The Times, 4 May 1867. 
As Justin McCarthy observed, to draw up such a petition as this, which put English policy in Ireland in much the same light as that of the Hapsburgs or Romanovs in relation to their subject peoples, was really "a very bold thing to do". ${ }^{1}$ Despite a passionate defence of the petition by John Stuart Mill, the House was most hostile. Tory backbenchers, under the leadership of Major Anson, declared that the petitioners had insulted the army, "thereby insulting the country itself". Despite the personal intervention of Disraeli they insisted on taking the unprecedented step of moving the discharge of the order of the House that the petition of E. Truelove and others do lie on the table. ${ }^{2}$ Anson's defeat in the division did not prevent Beesly being described as a friend of assassins, a man who was always "foaming at the mouth". ${ }^{3}$

The Positivists were always staunch friends of justice for Ireland and were the first influential body of Englishmen to concede that she had a right, not only to home rule, but to complete independence. ${ }^{4}$ It was this question that led Beesly to associate himself with the foundation of Hyndman's Democratic Federation in $188 \mathrm{I}$ and which caused the final rift between the Positivists and the Lib-Lab trade union leaders.

A few weeks after the rumpus over the Fenian Petition, Beesly made the speech in the Exeter Hall which is the best-remembered episode in his public life. The meeting had been summoned to condemn the terrorist outrages committed by Broadhead and his associates in the Sheffield saw grinders union. ${ }^{5}$ Beesly condemned the outrages, but went on to show how they were being used by a middle-class parliament and press as a pretext for a quite unwarranted blanket condemnation of trade unionism. A defensive attitude was a weak attitude. A trade union murder was neither better nor worse than any other murder. Governor Eyre was a "greater murderer" than Broadhead, but since his crimes were committed in the interests of the wealthy, the middle class did not condemn him but "offered him banquets", "loaded him with honours", "made his deed their own". The state of the law

1 McCarthy, J., The English Positivists, in: Galaxy (New York), March I 869.

2 The Times, is June 1867.

3 Mr. Beesly Again, in: The Pall Mall Gazette, i 2 Oct. 1867.

4 O'Connor, T. P., Professor Beesly, in: Reynolds News, I 8 July I9I 9.

5 For a detailed account of the outrages see Pollard, S., The Ethics of the Sheffield Outrages, in: Hunter Arch. Soc. Trans., I953/54. (Dr. Pollard appears to maintain the view that awareness of the diversity of morals must entail subjectivist conclusions about the relativity of moral judgements. It is important to note that this was not Beesly's position. His attitude was that while the existence of diverse moral codes was a factor to be taken into consideration in making a moral judgement, this was far from precluding the possibility of the judgement itself being true or false.) 
relating to trade unions was such that it allowed a magistrate to commit more outrages in a week than Broadhead had committed in a year. Since the law refused to protect trade union funds, the middle class was, in effect, encouraging thieves to do "what they were afraid to do themselves". Trade unionists must not allow themselves to be forced into the false position of doing penance for crimes they had not committed. They should redouble their demands for satisfactory labour laws, since it was "the sense of wrong legally inflicted which made unionists step outside the limits of legality". 1

This was a most effective speech, and Beesly was made to pay the price for it. The Times described his speech as "an offence against public and private morality, an exhibition as astounding and as disgraceful as the Sheffield outrages themselves". ${ }^{2}$ The Pall Mall Gazette stated that the Professor's mind "was cankered by a passion for setting workmen against their employers". ${ }^{3}$ The Globe asked whether Beesly aimed at being "the Marat of an English Revolution."4 Punch wanted him to change his name to "BEESTLY" and wanted an effigy of this "Precious Professor" to be put in Madame Tussauds." The press now discovered that Broadhead himself was only "a rougher and more vigorous Positive philosopher". ${ }^{6}$ On 27 th. July, 1867 , Sir F. H. Goldsmid, President of the Senate and member of the Council of University College, moved that consideration be given to the removal of Professor Beesly from his Chair, since his speech and his letters in his own defence showed him to be "unfit to be entrusted with the instruction of young men in History". " In the Reform Club steps were taken to have Beesly blackballed. ${ }^{8}$

However, his fellow Positivists, ${ }^{9}$ the London Trades Council ${ }^{10}$ and some eminent Liberals such as Goldwin Smith, ${ }^{11}$ rallied to his support. Marx - who never forgot this incident - sent an expression of sympathy and approval. In his reply Beesly observed, "I have had a great deal to bear both in public and in private, but $I$ have the satisfaction of not

1 Speech by E. S. Beesly in the Exeter Hall, in: The Bee-Hive, 6 July 1867.

2 The Times, 4 July 1867.

3 The Pall Mall Gazette, 10 July 1867 . (See also its comments on 3, 4 and 8 July 1867).

4 The Globe, 3 July 1867.

5 Punch, 13 and 20 July 1867.

- Unidentified press cutting in the Congreve Papers, Wadham College, Oxford.

7 Minutes of the Council of University College. (The Records Office, University College, London.)

${ }^{8}$ Beesly, E. S., to Congreve, 7 July $x 867$. (P.A. B.M.)

- Congreve R., Mr. Broadhead and the Anonymous Press, London (Truelove) 1867.

- Harrison, F., Letter in: The Pall Mall Gazette, I 2 July I 867.

10 Resolutions in support of Beesly in the Report of the various proceedings of the London Trades Council and the Conference of Amalgamated Trades, 1867.

11 Beesly to Congreve, 5 July 1867. (P.A. B.M.) 
having retracted anything, and I believe I shall have the further satisfaction of seeing those who have tried to visit me with penalties fail. The Council of the College decided yesterday to do nothing and I think other attempts will fail in the same way. ${ }^{1}$ But it has been a near thing and, after all, the combat is only adjourned. In some shape it must sooner or later be renewed, for when duty calls I hope I shall never be silent." 2

After the meeting in Exeter Hall, Marx sometimes accompanied Beesly to trade union meetings. ${ }^{3}$ Unlike the Professor, he took no public part in the proceedings. Indeed, it is remarkable how little attention Marx seems to have given to the Labour Laws agitation in England. He hardly mentions it in his correspondence, and seems to have made little attempt to exploit it as a school in which to develop the political consciousness of the English trade unionists. This remained the prerogative of Beesly and his fellow Positivists, who owed what influence they had in the Labour movement to the fact that their services as spokesmen and as political and legal advisers were always at the disposal of the trade union leaders. One must presume that Marx' theoretical work, and his obligation to keep abreast of international developments, prevented him from taking a more active part.

In addition to a general convergence of views on the immediate political tasks of the working class, and on other aspects of public affairs, Beesly's work as an historian was received by Marx with something which came near to approval, and Beesly returned the compliment by according recognition to the genius and erudition of the German socialist.

Beesly was not a scholar, and he stated quite frankly that he could never see any reason to over-exert himself with his professorial duties, which were both ill-paid and imposed upon him without adequate discussion or consultation. ${ }^{4}$ However, in the course of the sixties he produced a number of historical essays which were a stimulating

1 The attempts did fail, but Beesly had to endure nearly a month of uncertainty and anxiety. At University College only Grote had originally opposed interrogating Beesly; by a majority of 6 to 3 the Council found the Professor's explanation unsatisfactory, and it was not until 27 July, when it was proposed to take formal steps towards his dismissal, that he secured a majority against Goldsmid of 12 to 3. (Minutes of the College Council, Records Office, University College, London.)

2 Beesly to Marx. Letter headed "private" and dated 24 July i 867. (M.E.L.I.)

3 E.g., Meeting of the London Trades Delegates, in: The Bee-Hive, 17 Oct. 1868.

4 Kerr, W. P. (Editor), Notes and Materials for the History of University College, London, I 898, pp. 36-37. (Beesly contributed some observations.) 
challenge to conventional judgements. He trounced Charles Kingsley for denying that there were historical laws and so suggesting that history was not susceptible of scientific organisation and treatment. ${ }^{1}$ In 186 , he attempted to rehabilitate Catiline. ${ }^{2}$ Just as the time when - in Trevelyan's words - John Bright was being denounced as if he "had been the modern Catiline", ${ }^{3}$ Beesly was at pains to show that revolutionary heroes are always liable to be blackened by such "literary men" as Cicero, with his theories on "mendaciuncula". Karl Marx enjoyed this article, although Beesly's interpretation of Caesar was all wrong, and one noticed the absence of sustained critical sense - "as is to be expected in an Englishman". Since Frederic Harrison had an article in the same issue of the Fortnightly in which he stated that political economy could have no objection to Communism, Marx concluded that there was "at the moment, more movement in English heads than in German ones".4

Beesly's most important historical work in the sixties consisted of an essay which he wrote on "England and the Sea". In this work, the importance of discerning the class basis of maritime and foreign policies is much insisted upon, while attention is given to the economic causes of war. ${ }^{5}$ Marx makes no mention of having read this essay; if he did so he would certainly have been both impressed by it as well as irritated by its tedious references to "truth, morality and justice" - phrases which were not used in a way which he would have regarded as "harmless"."

Whether Marx read "England and the Sea" or not, he was at this time (1 866) finding himself obliged to pay some attention to Positivism. He told Engels that he was "studying Comte now, as a side-line, because the English and French make such a fuss about the fellow. What takes their fancy is the encyclopaedic touch, the synthesis. But this is miserable compared to Hegel." 7

Meanwhile the English Positivists were becoming increasingly interested in Marx' economic work. Eccarius had published a critique of Mill in the Commonwealth which had greatly impressed them. When they learned from Eccarius that he was no more than a humble

1 Mr. Kingsley and the Study of History, in: The Westminster Review, Apr. I86r. (This article was unsigned.)

${ }^{2}$ Beesly, E. S., Catiline as a Party Leader, in: The Fortnightly Review, June 1865.

3 Trevelyan, G. M., The Life of John Bright, London I913, p. 354.

4 Marx to Engcls, 19 Aug. I 865. (Marx/Engels Gesamtausgabe.)

5 Beesly, E. S., England and the Sea, being Essay III in International Policy, by Richard Congreve and others. London 1866 .

"See Marx on "truth, morality and justice" to Engels, 4 Nov. 1864. (Sel. Corr. Torr.)

7 Marx to Engels, 7 July 1866 . (Ibid.). 
disciple of Marx, who had just finished the first volume of Capital, they expressed a desire to study the book. ${ }^{1}$ Beesly wrote to Marx thanking him for sending him a copy in German, but confessing that he did not know that language. "I perceive", he wrote, "by the notes, that it is full of interesting matter and I gather that the diseases of society appear to you in the same light as they do me. Whether we should agree on the remedy I do not know and probably it is too much to expect. But when the world generally so persistently ignores the disease, there must be a wide field for our co-operation." 2

The form of co-operation which suggested itself to Marx was that Engels should write a review of Capital which Beesly would then help to get placed in the Fortnightly Review. Marx was - like many other people - under an erroneous impression that the Fortnightly Review and the Bee-Hive were "Comtist". ${ }^{3}$ Beesly was indeed on good terms with John Morley, the editor, who was very close to Positivism in the sixties, and he did his best to get the review published. However Morley thought that the article - although "irrefutable" - was too dry for his readers. ${ }^{4}$

Up until the late sixties there was one issue of immediate political importance upon which Marx and Beesly were definitely opposed, namely, on the correct position for workmen to take up in relation to the Second Empire. The attitude of Beesly and his fellow Positivists towards Bonapartism was decidedly ambiguous and unsatisfactory in the eyes, not only of Marx, but of most politically conscious workers. The Positivists were accused of being apologists for the tyranny of Louis Napoleon, and the fact that they had no simple rejoinder to this charge cost them dear.

Most of Marx' critical references to Beesly are bound up with this matter. Before the end of 1864 , he was complaining to Engels that Beesly and certain other littérateurs in the movement were so concerned to oppose the English aristocratic tradition that they were uncritically Francophil. He remarked that they had "a frantic love for France". In foreign affairs they held this love, not only for Napoleon I, but for "Boustrappa". 5 He found himself obliged to go out of his way

1 Marx to Engels, 27 June 1867 . (Marx/Engels Gesamtausgabe.)

2 Beesly to Marx, 24 Sept. 1867 . (M.E.L.I.)

${ }^{3}$ Marx to Engels, 24 Aug. and 99 Oct. 1867. (Marx/Engels Gesamtausgabe.) - For an accurate account of the relation of the Positivists to the Fortnightly Review, see the history of that journal by E. M. Everett, entitled The Party of Humanity (North Carolina, 1939).

${ }^{4}$ Marx to Engels, is Oct. I 868. (Ibid.)

5 As far as Beesly was concerned it would be quite untrue to suppose that he had any regard for the first Napoleon. Following his master, he regarded the Corsican as "the most formidable foe to civilisation the world has seen in modern times." (England and the Sea.) 
to deal with the mistaken attitude which these people encouraged on the Polish question. In the International he had to deliver "a brief historical lesson" showing "irrefutably" that "from Louis XV to Bonaparte III, the French had never ceased to betray the Poles". He also had to dispose of the inopportune conception - one which Beesly was certainly responsible for encouraging - of having the Anglo-French alliance, as the core of the International. ${ }^{1}$

It is clear from the fact that Marx spelt Beesly's name incorrectly, and wrongly described him as a Professor of political economy, that he was not well acquainted with him in I 864. However two years later we find him complaining that Beesly and "the whole clique of Comtists" were of the opinion that Bonaparte was to be thanked for saving Germany. ${ }^{2}$ While as late as 1869 Marx was reporting that Beesly had replied to a letter of his enclosing a pamphlet of Vermorel's in a manner which was "as stupid as it was pugnaciously pretentious". " "It seems to me", said Marx, "that positive philosophy equals ignorance of everything positive". "Presumably this relates to a letter of Beesly's in which he stated that, "I think it is quite right that the Paris workmen should bear in mind that the Opposition champions are thoroughly hostile to them on the most important questions; but whether it is wise and patriotic to urge them not to coalesce with the men of 1848 for the purpose of getting rid of Bonaparte is another thing. For my part I am inclined to think that the dethronement and punishment of the latter is so pressing a necessity that all differences should be sunk for the time". Beesly then embarked upon a criticism of Vermorel, charging him with being "too ready to denounce his opponents as villains". "I am not disposed to be tender to the bourgeoisie and their economic teaching. But I have no doubt that they sincerely believe that they have got hold of the true philosophy, and I dare say that as individuals they are neither better not worse than the partisans of the other schools. In fact I believe there is generally more private virtue on the side of the "status quo" than on that of the revolution. But just as I protest against Revolutions being judged by the lives of Revo-

\footnotetext{
1 Marx to Engels, ro Dec. I 864. (Marx/Engels Gesamtausgabe.)

2 Marx to Engels, 7 July 1866 . (Ibid.)

3 Auguste Vermorel: 184 1-1871. Proudhonist journalist. Editor of Le Courrier Français. Beesly ordered a copy of his Les Hommes de I 848. Presumably it was Vermorel's other work, L'Opposition, which Marx had sent to Beesly. Earlier Marx had sent Beesly the comments of Le Courrier Français on the Sheffield Outrage speech. Vermorel died on the barricades during the Commune. (See Cole: History of Socialist Thought, Vol. II.) For Marx' estimate of Vermorel's place as an historian participating in an "interesting movement which was preparing for the new Revolution" see his letter to Kugelmann of 3 March 1869.

4 Marx to Engels, 20 March 1869 . (Ibid.)
} 
lutionists, so I think it is a mistake to suppose that a conservative is likely to be a bad man because he defends a bad cause." I

One can well imagine Marx writhing with indignation as he read these - to him - inexcusably fatuous and superior remarks. Since the letter as a whole is not representative of Beesly's outlook, it requires some explanation. The first two sentences are not exceptional. In suggesting "a popular front" against the Empire, Beesly was simply adopting a position analogous to that which he took up towards union between the workers and Bright on the Reform issue. Marx seems to have ignored or dismissed as unworthy of consideration, Beesly's repeated insistence that union between workmen and bourgeois radicals needed to be accompanied by a perfect recognition on the part of the former of the primary importance (in the longer run) of the antagonism between their interests and those of their temporary allies.

The rest of the letter, the lapse into the strangely detached attitude is more difficult to explain. Presumably Beesly intended that this homily on the virtue of the bourgeois oppositionists would help to persuade Marx of the wisdom of encouraging workmen to collaborate with them against Napoleon. Fundamentally, it proceeded from confusion, from the fact that Beesly was just awaking from his dogmatic slumbers so far as Bonapartism was concerned, and was still engaged in regrouping his thoughts on French politics. He soon took a very different view of the relative virtue of bourgeois and proletarian in France and, within a few months, he was publicly declaring that it would be better for the Empire to last a little longer rather than that the workers should overthrow it for the benefit of Thiers and Jules Favre. ${ }^{2}$

The important thing was that Beesly had "come to his senses" with regard to Louis Napoleon. In the past he had written in the workingclass press in extenuation of the coup d'état, pointing out, as he still insisted in 1869 , that it had been directed at "the middle-class liberals, who had shed the blood of the people like water in June, I 848, by the hands of General Cavaignac". ${ }^{3}$ Similarly, he had directed ironic shafts against the democratic critics of the Empire - men who were still in the "metaphysical stage" - by arguing that, since despotism pressed alike on all classes in France, "the principle of equality was in no way infringed". ${ }^{4} \mathrm{He}$ had tried to persuade the readers of the Bee-Hive that there were two Napoleons: one was the objectionable person who imposed restrictions on the freedom of the press, the other was the

1 Beesly to Marx, 6 [8 ?] March I 869. (M.E.L.I.)

2 Beesly, E. S., Napoleon III, in: The Birmingham Weekly Post, i I Dec. 1869.

3 Beesly, E. S., Napoleon and his Policy, in: The Bee-Hive, I9 Dec. I 863.

4 Ibid. - This is the most charitable interpretation of this passage. 
man feared by the privileged classes throughout Europe, the true heir of the Revolution. ${ }^{1}$

Up until about 1867 , the other Positivists shared these views. But in that year, Harrison became convinced - as a result of the Mexican campaign, the intrigues with Bismarck and the Italian policy - that "the first condition of progress is now, - the fall of the retrograde Imperial throne". ${ }^{2}$ By 1869 Beesly himself had no hesitation in describing the Emperor as an unprincipled criminal, whose concessions to the workers (repeal of the combination laws and abolition of the livret) were solely designed to cow the bourgeoisie by suggesting that, if driven to extremities, he would throw himself upon the proletariat. ${ }^{3}$

Comte had made his peace with Napoleon because - as the philosopher himself expressed it - "the actual form of dictatorial power in France.... permits the direct propagation of all thought that has a tendency to reconstruction." He had gone on to defend this dictatorship by asserting that "it has at last broken the power that could lead to no good, that of mere talkers".

By the end of the sixties, the English Positivists were witnessing the Emperor's restoration of an Assembly of "mere talkers", while a French proletarian co-religionist was sent to Ste. Pelagie for daring to associate himself with the International. ${ }^{4}$ Napoleon's fault was not that he had disposed of Parliamentary government and assumed absolute powers, but that he had done nothing worth while with the power acquired. He had argued - quite rightly in Beesly's eyes - that Parliamentary government was unsuited to France, but he had then gone on to show that in the interests of vulgar ambition he was prepared to put up with it, if personal sovereignty was no longer to be had. Throughout most of 1869 and all of 1870 , Beesly considered Ireland, pauperism, the Trade Union Bill - although all of them questions of the "first magnitude" - less important than "the progress of the Revolution in France". "If the Empire does not fall at once before the hatred and contempt of Paris", he wrote, "it is because the bourgeoisie are profoundly afraid of the workmen, and wish to establish some form of Parliamentary government, which, like all Parliamentary governments, would be purely to the advantage of the non-workman class.... It is certain that the establishment of a

1 Beesly, E. S., The Paris Elections; and: Napoleon and the Congress, in: The Bee-Hive, I3 June I 863 and s Dec. I 863.

2 Harrison, F., Napoleon and Italy, in: 'The Bee-Hive, II Nov. 1867.

3 Beesly, E. S., Napoleon III, in: The Birmingham Weekly Post, i I Dec. I869.

4 Beesly, E. S., The International Working Men's Association, in: The Fortnightly Review, Nov, 1870; and Mollin, G., Rapport sur le Congrès de Bâle, Paris 1870.

5 Beesly, E. S., Rochefort, in: The Birmingham Weekly Post, 22 Jan. 1870. 
Republic would soon be followed by an agitation on industrial questions, and when that struggle begins, the shock will vibrate through Europe." 1 For more than a year before the Commune he continually speculated on "whether the brave, but unarmed workmen of Paris can do in 1870 what they did in 1848 and $1830 \ldots " 2 \mathrm{He}$ foretold that when they did make their Revolution they would do much of which he could not approve, but swore that he would not judge them too harshly. ${ }^{3}$

In view of all this it is not surprising that only a few weeks had to elapse after the Vermorel episode before Marx and Engels were noting an "improvement" in Beesly. He had sent Marx a letter enquiring after Lafargue whom he feared might have been arrested in Paris, and had gone on to announce his engagement to the sister of a fellowPositivist, Henry Crompton." "She is", he told Marx, "heartily sympathetic with my political and social views and there is no fear that I shall have to become respectable." " 5 Marx was soon furnished with evidence that Beesly meant to be as good as his word as far as respectability was concerned.

On the evening of $23 \mathrm{rd}$. June, 1869 , a mass meeting of London trade unionists was held in the Exeter Hall. Its purpose was to support the Trade Union Bill which had been drafted by Frederic Harrison on the basis of the Minority Report of the Royal Commission of I 867-69. Hughes and Mundella had agreed to introduce the Bill, but they were being subjected to heavy pressure to withdraw it. Henry Crompton, speaking from personal observation, declared that a regular process of "ear-wigging" was going on. "Even the opinions which Mr. Harrison and I held about Positivism were used to malign

1 Beesly, E. S., Napoleon III, in: The Birmingham Weekly Post, I I Dec. I 869.

2 Beesly, E. S., Rochefort, in: The Birmingham Weekly Post, 22 Jan. 1870.

${ }^{3}$ Beesly, E. S., French Prospects, in: The Birmingham Weekly Post, 29 Jan. 1870; and A Word for France, London (Truelove), Sept. 1870.

4 Henry Crompton: 1836-1904. Born at Liverpool; the son of a distinguished judge, and elder brother of Albert Crompton who was also a Positivist. Crompton met Beesly in 1864 , and on the latter's recommendation, was nominated as one of the foundation members of the London Positivist Society which was formally established in 1867 . Crompton was for 43 years Clerk of Assizes on the Chester and North Wales circuit. He was actively associated with Beesly, Harrison, Godfrey Lushington and other Positivists in the direction of the Trade Union labour laws agitation from 1867 . Between 1871 and I 88I he was the most directly influential adviser of the trade union leaders, and on more than one occasion he drew up practically the entire programme of the T.U.C. He was actively interested in industrial arbitration, and was the author of one of the first substantial works on this topic. (D.N.B. and obituary by Beesly, in: The Positivist Review, May 1904.)

5 Beesly to Marx, 2 I May I869. (M.E.L.I.) 
this simple demand for justice. It was whispered that the Trade Union Bill meant Red Republicanism, Communism, Atheism. ${ }^{1}$

At this gathering Samuel Morley ${ }^{2}$ was in the chair, Beesly on the platform and Marx an interested spectator. ${ }^{3}$ Since Sam Morley invested large sums of money in the Labour movement with the object of subordinating it to the Liberal party, ${ }^{4}$ the prospects for the success of the meeting in strengthening the resolve of Hughes and Mundella to persist with their measure were none too good. But Beesly was determined that the Bill should be forced to a division on the Second Reading so that workmen should see their "Liberal friends" for the dishonest procrastinators which he took them to be. His speech was therefore short, sharp, and based on a call for an uncompromising class struggle in the interests of the Bill. It contained a reference to the "days of June" at which "Karl Marx grinned a ghastly grin and Sam Morley smiled a sickly smile". Marx was indeed delighted with the cool nerve with which Beesly pilloried everything which Morley stood for. ${ }^{5}$ At this time the two men had both dissociated themselves from the Bee-Hive, which had been partly wrested out of the control, of Potter by philanthropists of the Morley variety, and was consequently in the process of exchanging politics and pornography for moral uplift.

\section{III}

However, the period of really close association between Marx and Beesly did not begin until twelve months later. For it was the FrancoPrussian War and its aftermath which provided them with an occasion for serious collaboration. Between September I870 and the end of the following year this collaboration took four main forms. They worked

1 Crompton, H., The Defeat of the Workmen, in: The Bee-Hive, 2 Sept. 1871.

2 Samuel Morley: 1809-1866. The largest hosiery manufacturer in England and one of the wealthiest men in the country. He worshipped God and Mr. Gladstone in about equal proportion, being a munificent builder of chapels and a generous donor to the coffers of the party. Of him it was said, "He erected benevolence into a business." Together with James Stansfeld and G. G. Gynn, joint secretaries to the Treasury in Gladstone's first administration, he spent hundreds of pounds in order to line up working-class voters behind the Liberal party. W. R. Cremer and George Howell received $£ 200$ for their services in administering a special fund to which Morley subscribed $£ 2,000$ during the election campaign of $\mathrm{I} 867-8$. He also interested himself in the press and had a small financial interest in the Bee-Hive. (See D.N.B. and the "Life" by E. Hodder. Dr. Stephen Coltham's promised "History of the Bee-Hive", and my own forthcoming work on the Positivists ought together to give a fuller picture of Samuel Morley's activity in the labour movement.)

${ }^{3}$ Meeting of London Trade Unionists in the Exeter Hall. The Bee-Hive, 26 June I 869.

4 G. Howell to S. Morley, I Dec. I 868. (B.I.)

5 Marx to Engels, 26 June I 869. (Marx/Engels Gesamtausgabe.) 
together to arouse sympathy for the French Republic - while differing on the sort of demands which they believed should be presented by the workmen to the Gladstone government; they tried to inform public opinion about the aims of the International; together they defended the Commune, and together had to endure the consequences of this defence; finally they were associated in trying to alleviate the sufferings of the Communard refugees.

On 12 th. September I 870 , Marx wrote to Beesly asking him to help raise money for the wife of Auguste Serraillier. (Serraillier was a member of the General Council who had gone to Paris. His wife, according to Marx, was left "sans sou", and threatened with eviction.) Marx then went on to state

"You will find that the Address I laid before the General Council, Friday last, and which is in the course of printing, coincides on many points almost literally with your pamphlet. ${ }^{1}$

My opinion is that Paris will be forced to capitulate, and from the private letters I receive from Paris it appears that some influential members of the Provisional Government are prepared for such a turn of events.

Serraillier writes me today that the haste with which the Prussians march upon Paris is the only thing in the world able to prevent a new Insurrection of June! Paris fallen, France will be far from lost if the provinces do their duty.

The Federal Council of Paris bombards me with telegrams, all to this effect: Recognition of the French Republic by England. In point of fact it is most important for France. It is the only thing you can at present do for her. The King of Prussia treats officially Bonaparte as the ruling Sovereign of France. He wants to restore him. The French Republic will not exist officially before its recognition by the British Government. But no time is to be lost. Will you allow your Queen and your oligarchs, under the dictation of Bismarck, to abuse the immense influence of England?"

In a postscript which is of great importance for the understanding of subsequent events, Marx explained that a repudiation of the Treaty of Paris (1856) would allow Britain to bring her great naval strength into effective play, and change the tone in which continental bullies addressed England. ${ }^{2}$

1 Marx is referring to Beesly's pamphlet, A Word for France.

2 Marx to Beesly, Iz Sept. 1870, in: The Social-Democrat, Vol. VII (I903), pp. 229-23 I. 
During the first few weeks of the Franco-Prussian War, the Positivists had been obliged to remain silent. They could not defend French aggression, and they sincerely hoped that her army would be defeated and the criminal regime of Louis Napoleon overthrown. But by mid-August Congreve was already beginning to suggest that the situation was one which called for the united action of the neutral states of Western Europe. ${ }^{1}$

Basic to the English Positivists' appraisal of international affairs was Comte's conception of the "Republic of the West". The République Occidentale would put upon a definitive and systematic basis what had earlier been the imperfect unity of Christendom under Rome; the object of Henry IV's "Great Design"; the aspiration of such progressives as Victor Hugo towards a "United States of Europe". Accordingly, a war between any of the "five Great Countries of the West" was a Civil War which it was the duty of the others to bring to a swift and just conclusion. ${ }^{2}$ The tragedy of 1870 lay in the fact that the foremost nation of the West had allowed herself to embark upon an aggressive war, and in consequence was in danger of being overrun by the most militaristic and retrograde of her neighbours.

However, the moment that the Republic was proclaimed in Paris, the Positivists declared that the war had changed its character and threw themselves with a desparate enthusiasm into the task of arousing the British working class on behalf of France. This was a task in which they needed no encouragement from Marx. On the very eve of Louis Napoleon's fall, Congreve had placarded London with an address to Englishmen, "especially Englishmen of the working classes". ${ }^{3}$ On

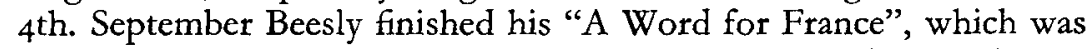
soon selling in thousands of copies among the London workmen.

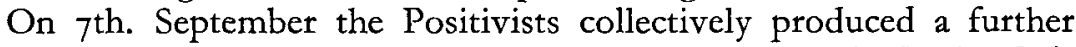
pamphlet, and Dr. Bridges brought out a two-page leaflet headed: "Why we should stand by France: Because we owe to France our Greatest Progress in the Past: Because we hope from France our Greatest Progress in the Future."

On roth. September Congreve produced an expression of his devotion to Paris in the shape of yet another leaflet. It was perhaps the most eloquent and intelligible thing which he ever wrote. Although

1 Sémerie, E., Les Positivistes Anglais pendant la dernière guerre, in: La Politique Positive, I re année (1 $872-3$ ).

2 Marx himself, incidentally, was not opposed to describing a war between France and Germany in these terms. See his letter of Io Sept. I 868 to J. G. Eccarius and F. Lessner. (Selected Correspondence, 1956.)

${ }^{3}$ Congreve, R., The war in the Name of humanity, proof copy of placard from the printers, Wyman \& Sons, 3 Sept. 1870. 
it was addressed to Londoners, it was translated into French and posted up upon the walls of Paris. ${ }^{1}$ It began "The Prussian King, an old soldier, a mere soldier, incapable of any higher notion than that of a soldier's glory, impenetrable to all the better tendencies of our time, or viewing them with a King's instinctive hatred, is marching upon Paris."

It continued:

"The death-duel may even now have begun, and the city may have heard the first boom of the Prussian artillery. And we - what are we doing? What is England doing? Her Queen is in the Highlands, away from the care and trouble; reading, possibly with sympathy the last devout despatch of her royal compeer of Prussia, and indulging in satisfaction over the glorious prospects of her daughter's husband. Her Ministry is silent, and apparently careless. Her Premier visiting exhibitions or Clumber. Her foreign Secretary enjoying Walmer. The First Lord of the Admiralty in Belgium; the rest, here, there and everywhere. Her nobles and gentry are bent on their annual game destruction - is it not the season of that mighty interest? Her commercial classes counsel peace; her press preaches submission. No hand is raised; - no voice, even in sympathy.

Men of London, we may awake one morning and find that the death struggle is over, and that through the smoking ruins of Paris, bombarded and taken by storm, the ministers of German vengeance and German greed are raising their hoarse psalm - it will be of course a psalm! - to the God of Battles."

While Congreve was writing this appeal, Beesly was descending upon a mass meeting organised by Edmund Beales' Workmen's Peace Association. He rose from the body of the Hall, and demanded the right to put an amendment which called upon the Government to do all in its power to preserve the territorial integrity of France. "The pugnacity of the learned gentlemen was evident from the manner in which he advanced to the table, and then impatiently waited, standing, the termination of Mr. Beales' remarks; he then gave himself ten minutes by his watch to move the rider, stating during his speech that he was prepared for contingencies and had a seconder ready to hand; whereupon up jumped Mr. Applegarth with surprising agility from the body of the Hall, like a jack-in-the-box, and, after a few explosive remarks, disappeared." 2 The division on the rider was

1 Congreve, R., Paris, 17 Mecklenburgh Square, Io Sept. I870. Reproduced in Le Chevalier, Murailles Politiques, Paris I 874 .

2 "One who was present": a letter so signed, being a newspaper cutting pasted into the back of a pamphlet in the Howell Collection, No. 1705, Class 331.89 . (B.I.) 
a close one, but a reluctant chairman had to declare it carried. Next day Beesly was in Hyde Park addressing a vast meeting which resolved to send George Odger to Paris with greetings to the Provisional Government. ${ }^{1}$

All this activity by the Positivists took place before Marx appealed to Beesly to arouse opinion against "Queen and oligarchs". It should, therefore, be concluded that Marx' purpose was not to rouse Beesly to action, but to modify the direction of his activities. Beesly's reply suggests that he did not appreciate this. What really impressed the Positivist was the identity between his position expressed in "A Word for France" and the two Addresses of the International on the War. This was not surprising, for Beesly had anticipated Marx in insisting upon the changed character of the War; in emphasising the bourgeoisrepublicans' fatal dread of the French working class; in disposing of German arguments for "a sound strategic frontier"; and in foretelling a Franco-Russian Alliance and a new war in the event of annexations. Marx was not exaggerating when he referred to passages which coincided "almost literally". In particular, this was true of the terms in which the Prussian military system and the delusion of German peaceableness were described. ${ }^{2}$

Consequently, Beesly replied to the letter of 12 th. September by stating,

"I not only most thoroughly endorse your two addresses, but I think their importance can hardly be over-rated. They are admirably reasoned and the spirit is excellent. I now recognise as I never did before, the usefulness of the International, and I regret that $I$ have not cooperated with it actively in the past, though I have always sympathised. It is clear that this plague of militarism in France, and still more in Germany, can only be got rid of by the promotion of a social and industrial spirit among workmen, and a belief that their interests are the same throughout Europe.

I am afraid that you and I differ rather widely in our economic doctrines; but at least we agree in this, that all our social arrangements have been made formerly[?] ${ }^{3}$ by the non-workmen and will continue to be so until the workmen know their strength and use it."

1 Meeting in Hyde Park. The Bee-Hive, 17 Sept. 1870.

2 Beesly, E. S., A Word for France: on German peaceableness, p. 8 para. 3 ; on the German military system (soldiers on furlough), p. 6 lines 8-12. Compare with Second Manifesto of the General Council, para. I : "But, say the mouthpieces of Teutonic patriotism..." ${ }^{3}$ In the photostatic copy of this letter this word is indistinct. 
He went on to state that he "entirely distrusted" the Provisional Government, and agreed with Marx that, from the workers' standpoint, most of them were no better than Thiers. However, he went on to add that, "A Socialist outbreak just now would set all the Governments in Europe against France when she needs their open or covert assistance", - a statement with which Engels, at any rate, agreed, although he doubted the possibility of a war of National Defence. ${ }^{1}$

Having stressed the importance of the area of their known agreement, Beesly concluded by assuming that it went still further. Referring by implication to the Workmen's Peace Association, he observed, "What a pernicious old goose Beales ${ }^{2}$ is. He is expecting a County Court judgeship and is on his good behaviour." 3

In his letter Beesly had asked Marx to tell him if he could cooperate with him to any purpose. It would appear that Beesly had but to mention this word to Marx for the latter's thoughts to turn instantly to the Fortnightly Review. For he replied at once and - after some references to the latest European developments - proposed that Beesly should write an account of the International for that journal. Since Beesly was a Positivist it was a matter of principle with him to despise the press and to express unlimited contempt for anonymous journalism. Marx cunningly played upon this and expatiated at some length upon "the utter corruption" of the London press, which repressed all the pronouncements of the International, and which was still the "vile concern" which Cobbett had long ago branded as "mercenary, infamous, and illiterate".4

Beesly at once expressed his willingness to write the article, but explained that he would have to depend on Marx for the materials. ${ }^{5}$ Subsequently he arranged to call on Marx and sort these out. ${ }^{6}$ Whether or not this arrangement was kept is unknown, but Marx apparently furnished Beesly with a manuscript which - because of the wellknown illegibility of Marx' handwriting - the Professor had some difficulty in reading. ${ }^{7} \mathrm{He}$ asked Marx to explain the political position

1 Engels to Marx, 12 Sept. I 870 . (Sel. Corr. Torr.)

2 Edmund Beales: 1803-1881. President of the Reform League and actively associated with international democratic movements of the early sixties. George Howell, and other working-class associates of Bcales, organised a testimonial fund for him and helped him to get the Judgeship. He worked with Cremer in the peace movement. (D.N.B.)

3 Beesly to Marx, I4 Sept. 1870 . (M.E.L.I.)

4 Marx to Beesly, I6 Sept. I 870.

(Karl Marx and Frederick Engels on Britain, Moscow 1953; London 1954.)

5 Beesly to Marx, i 8 Sept. I 870 . (M.E.L.I.)

- Beesly to Marx, 20 Sept. 1870 . (M.E.L.I.)

7 Beesly to Marx, 2 I Oct. 1870 . (M.E.L.I.) 
of Deak in Hungary, and to furnish him with "a short statement about recent events in Lyons" where a revolutionary government had been established. ${ }^{1}$ Marx replied to these questions by saying that Deak was "a Hungarian edition of an English Whig", while, as far as Lyons was concerned, he had "received letters not fit for publication", reporting on the anarchist activities of "the asses, Bakunin and Cluseret", who were misleading people and issuing "most foolish decrees on the abolition de l'état". ${ }^{2}$

Discretion came hard to Positivists, who had to follow their Master's injunction to "Live Openly", but Beesly not only remained silent about Lyons, but deliberately refrained from discussing the origins of the International, since this would have involved him in giving incontrovertible figures about its - very small - English membership. ${ }^{3}$

The article appeared in the November issue of the Fortnightly. Although it could never have been written without Marx' help, and although Marx was consulted continuously, and even sent the proofs, it was Beesly's work. It could quite properly be regarded as in direct line of succession to earlier pioneer studies made by Beesly and Harrison of proletarian organisations and movements - studies which influenced the Webbs and foreshadowed their work. ${ }^{4}$

In his article Beesly gave a careful but brief account of how the I.W.M.A. was established, and traced its history through the London Conference of 1865,5 and the Congresses at Geneva, Lausanne, Brussels and Basle. He described the services rendered by the International in a number of leading industrial disputes. On the whole, he made light of theoretical questions, reserving unqualified praise for the speech made by his co-religionist Mollin the metal-gilder, at the Basle

1 Beesly to Marx, $x 8$ Oct. 1870. (M.E.L.I.)

2 Marx to Beesly, I9 Oct. I 870 . (Sel. Corr. I956.)

3 Beesly to Marx, 24 Oct. I 87 o. (M.E.L.I.)

4 Beesly, E. S., The Amalgamated Society of Carpenters, in: The Fortnightly Review, May 1867. - Harrison, F., The Ironmasters' Trade Union, I 865. (Both these articles were reprinted in the A.S.C.J. Monthly Report.)

5 Unfortunately the article throws no light on an episode which, if it was cleared up, might throw additional light on Marx and Positivism. According to Kautsky's notes of Engels' reflections on the History of the International, Marx insisted that at the first Congress of the International, there should be a discussion of "The Religious Idea in its relation to the social, political and intellectual development of the pcople". Lessner and George Howell also state that Marx made this proposal. Marx denied Howell's account of the matter, without clearing up the origin of the story. According to Mr. Henry Collins, who is writing a history of the I.W.M.A. in England, Marx put this resolution, but only in order to get it out of the way. It originated with the French Proudhonists. See Kautsky's notes on conversations on the I.M.W.A. with Engels. (I.I.S.H.) - Lessner, F., Sixty Years in the Social-Democratic Movement, London 1907, p. 35. - Howell, G., The International, in: The Nineteenth Century I878, Vol. IV, pp. 19-40. 
Congress. For the rest, he commended the "practical English element", which he credited with saving the organisation from disastrous splits over matters of political and economic theory. It was - in Beesly's view - sufficient unto the day that the International was republican and anti-militarist. "Let not cynical politicians imagine", he wrote, "that the protest of the workmen of Europe against war is to be ranked with the hollow unreasoning sentimentalities of the press, the pulpit and the countinghouse. In England they mean to have their way about this thing and they will grind to powder all institutions, classes and interests that attempt to militarise them, whether as regulars, militia, reserves, volunteers or anything else."

Marx was not likely to be greatly disturbed by Beesly's slight estimate of the theoretic principles of the Association. One doubts whether he was even very much distressed by having certain absurdities fathered upon its "German" theoreticians. The Professor had atoned handsomely for these blemishes by referring to the Inaugural Address as "probably the most striking and powerful statement of the workman's case as against the middle class that has ever been compressed into a dozen small pages." Beesly introduced Marx to the British public as the man most responsible for the success of the International, and declared him to be probably the greatest authority upon the history and statistics of the Labour Movement in all Europe. ${ }^{1}$

Apart from this being personally gratifying to Marx (and his wife), the article was of considerable political importance. Beesly had provided the most complete description of the International to appear in England or anywhere else, and had presented it as a serious and powerful force. By doing so he helped to link its name in the public mind with the momentous events which were shortly to shake European society to its foundations.

In writing this article and in speaking in support of the International at the London T.U.C. held at the beginning of $187 \mathrm{r},{ }^{2}$ Beesly can hardly have been unaware of the thoroughly hostile attitude which Marx adopted, not only towards Comte, but against Positivism as an organised force within the International. Five months before Beesly published his work in the Fortnightly, Marx had tried to prevent the admission of the Parisian Proletarian Positivists as a section of the I.W.M.A. He described them as sectarians who "were against every religion but Comte's" and whose rules were too exclusive to allow

1 Beesly, E. S., The International Working Men's Association, in: The Fortnightly Review, Nov. 1870.

${ }^{2}$ Speech by E. S. Beesly on the sixth day of the T.U.C. in London, The Bee-Hive, I 8 March 1871 . 
of their affiliation. ${ }^{1}$ It turned out that the Positivists were already affiliated, but Marx did not cease to pursue them, and the resolutions of the secret London Conference of $187 \mathrm{I}$ which ordered their dissolution were not simply designed to give the appearance of a rule of law against the Bakuninists. ${ }^{2}$

However, it was not this matter which threatened to bring about a serious clash between Marx and Beesly at the end of 1870 , but rather the differences between them as to the character which ought to be given to the Republican and pro-French agitation.

In September 1870 Beesly had observed to Marx that "public feeling [on the Franco-Prussian War] is getting better every day." He went on with a sentence which was more in keeping with Marx' character then with his own: "I do not anticipate that England will act even in the mildest way. But all this excitement is leavening the mass for us." 3

While not anticipating that England would act, Beesly and his friends continued to exert every effort to that end. From hinting at the need for armed intervention they passed on to openly demanding it. Congreve presided over a body styled the Anglo-French Intervention Committee which was made up of representatives of the Land and Labour League and the International Democratic Association. ${ }^{4}$ (Both these organisations were led by men who were associated with the International, and who took on its colouring without properly grasping its ideas. Marx was unable to control them and found them an increasing embarrassment.)

It was largely as a result of this continuous Positivist pressure that the leading trade unionists of London were brought into the campaign. Towards the end of the year they helped to organise an enormous deputation, made up of representatives of more than a hundred Unions, which waited upon Gladstone to demand a strong policy from his government. What they wanted the Premier to pledge himself to was not merely "Recognition", but "No Spoliation" of France by Germany. ${ }^{5}$ Soon they had whipped up such enthusiasm for France that War on her behalf seemed acceptable to many workmen. Even George Howell thought it proper to strike attitudes: "Don't wonder if I go to the front", he wrote, "for I am getting martial in my

1 Minutes of the General Council, Is March 1870 . (I.I.S.H.)

2 Resolutions of the Conference of Delegates of the International Working Men's Association assembled at London from 17 th to 23 rd September 1871 , London 1871 .

3 Beesly to Marx, 20 Sept. 1870 . (M.E.L.I.)

4 Harrison, R., The Land and Labour League, in: Bulletin of the International Institute of Social History, Vol. VIII (1953), Nr. 3, pp. 169-195.

5 A Remonstrance to Gladstone, in: The Bee-Hive, 7 Jan. I871, 
thought and bearing. There is no knowing what a wild enthusiasm may bring forth, and I have no very good reason for life and never had." 1 No doubt Marx and Engels thought it a pity that workingclass sympathy should run to waste in such preposterous fantasies as these, and they blamed Beesly and his friends most sincerely for it. On 3 rd. January i 87 I Marx cautioned members of the General Council against blindly following the lead of Professor Beesly and his friends. To begin with, the Positivists had called a mass meeting on what Marx considered (incorrectly) to be an inappropriate night. Then, - much worse - Eccarius had signed the memorial to Gladstone, which had been drawn up by the Positivists, without having first consulted the appropriate sub-Committee of the General Council. Marx did not dissent from the general sentiments expressed in this memorial, but he thought that the final paragraph, which called for war upon Prussia if she refused to make peace on reasonable terms, might have been improved. ${ }^{2}$

On 3 Ist. January Friedrich Engels submitted three resolutions to the General Council which, he suggested, ought to serve as a basis for discussion. The substance of these resolutions was that the English working class ought to have confined its efforts to securing the Recognition of the Republic; that English military intervention on the Continent could only have been effective during one brief phase of the war: a phase which had long since passed; and, finally, that the key to effective British intervention in Europe was the repudiation of the Treaty of Paris, in so far as this limited the full exercise of British naval power.

Engels argued that had the British working class confined itself to getting Gladstone to recognise the Provisional Government, it might have succeeded, "but", he declared, "there were others who were not satisfied with this. I mean the Comtists, Professor Beesly and his friends. Professor Beesly has on several occasions stood up boldly for the working class... but the Comtists are not properly a workingclass party. They advocate a compromise to make wages labour tolerable, to perpetuate it; they belong to a political sect who believe that France ought to rule the world. In their last declaration, which was signed by several members of the Council, they demand that France should be restored to the position it occupied before the war. Before the war, France was a military power. The Comtists asked for intervention, and as soon as that was done, the working-class movement split up.... How could people who were not able to compel the

1 G. Howell to C. Bartlett, i Sept. I 870 . (B.I.)

2 Minutes of the General Council, 3 Jan. I 87 r.(I.I.S.H.) 
Government to recognise the Republic, force the same Government to go to war for the Republic?" 1

To have said that the Positivists thought that "France ought to rule the world" was caricature. Only a few days before Engels spoke, Congreve himself had explained "that whilst speaking, to a superficial judgment, merely in favour of France, it has been, I repeat, in no partisan spirit. We have not held her to be by any peculiar law exempt from the consequences of her mistakes; we have attached no peculiar sacredness to her political greatness or the integrity of her soil... we have spoken quite as much in the interests of Germany as that of France. We have viewed both equally as constituent members of one great body politic, and have wished equally the peace and happiness of both." 2

However there can be no quarrel with Engels, passing judgment in his character as "the General", on the extremely limited possibilities of British military intervention. In his old age Beesly confessed that "after the rapid destruction of the French army, no interference of ours would have been of much avail unless other powers had been ready to join in." 3

The most interesting problem is to determine the legitimacy of Engels' back-handed tribute to Positivist influence, namely his charge that they were responsible for splitting the working class. To a superficial judgment there might seem little evidence to support Engels here. The middle-class press, if it bothered to refer to working-class opinion at all, suggested that its main characteristic was the somersault it had performed since September. This was the interpretation which Punch suggested:

"Yes, Mr. Merriman, sound your alarms, Odger and Applegarth, shout ye: 'To arms!' At the war's outbreak you peace were all for, Now have your windpipes grown trumpets of war." 4

John Stuart Mill blamed the Positivists, not for dividing the workers, but for uniting them behind the demand for war. ${ }^{5}$

On the General Council, Engels' standpoint was indirectly challenged

1 Minutes of the General Council, 3 I Jan. 187 I. (I.I.S.H.)

${ }^{2}$ Congreve, R., Religion of Humanity.... An Address on the Festival of Humanity, Sunday, I Jan. I87I, in: Congreve, R., Essays, London I874, Vol. I, PP. 402-3.

3 Beesly to Dr. Hillemand, 25 Dec. 1908. (M.A.C.)

4 A Whoop for War, in: Punch, 28 Jan. 1871.

5 See Raymond, D. N., Contemporary British Opinion during the Franco-Prussian War, New York $192 x$, pp. 288-9. 
by Weston, who not only defended collaboration with the Positivists whenever they were found to be advocating a proletarian standpoint, but declared that "the division among the working class had existed prior to the proclamation of the Republic and had been brought about by the Workmen's Peace Society declaring that England should on no account take part in the War". ${ }^{1}$ Marx himself had laughed to scorn the excuses which Hales and Harris (members of the General Council) had given for not taking part in the Positivists' "war" meeting in St. James' Hall, since they had fallen into a trap laid for them by Cremer and the Peace Society. Cremer's denunciations of the Positivists were, said Marx, "not worth anything". The Positivists were "the only people who did anything in this question." 2 However there can be no doubt that Marx was basically in agreement with Engels.

In fact, Engels' charges were perfectly justifiable. Some interesting corroboration of them is furnished by a police report of the period. This report attempts to trace the growth of the Republican movement among the working class. It notices that Beesly joined in, once the French issue arose. Having made some suitable observations to the effect that the "quasi-respectability" of such men ought to have separated them from those who referred to Mr. Gladstone as "Coercion Bill", and to Her Majesty in "terms that would befit a brothel", the author of this report goes on to state that the agitation soon "fell to such a depth of folly that the demand was made that England should immediately declare war against Prussia". At the meeting of Igth. October it was said that "even Osborne and Owen had sense enough to secede from their confederates". ${ }^{3}$

But there is no need to substantiate Engels' charge from such bizarre sources; the Positivists themselves confessed to having introduced what Holyoake called "division-stirring issues". They were guilty - if that is the correct expression - of "blaming the Government - scolding Lord Mayors - vituperating Prussia - affirming Republicanism - proposing an armed intervention - proclaiming the sacredness of the soil of Auguste Comte". ${ }^{4}$ For the most important of these offences they admitted their responsibility and agreed that they divided the workers.

In September 1872 , Congreve visited Paris, where he delivered an

1 Minutes of the General Council, 2 I Febr. 187 I. (I.I.S.H.)

2 Ibid., 3 Jan. 187 I. (I.I.S.H.)

${ }^{3}$ Summary of Police Reports registered in the Home Office with reference to political meetings held in the metropolis during the years 1867 -1 870 inclusive, Gladstone papers, Brit. Mus., 44617 , f. 95 .

4 Holyoake, G. J., Letter in The Bee-Hive, 7 Jan. 1871. 
address to his co-religionists upon the "Union of the English and French Proletariats". In the course of his remarks he recalled that he had seen the workers of London at close quarters during the war and he wished to pay tribute to their great qualities. "They were", he said, "practically unanimous in proclaiming the French Republic, and always insisted that the Government should recognise it without delay. But when it came to the question of war, the division was very pronounced: they drew back before this prospect, and this division was fatal to the exercise of all serious influence upon the general politics of the country." 1

Even at the time of the agitation Congreve had been in no doubt of the position. "The working classes in London are sound in their sentiments but divided as to their action; some are for intervention, others against anything but moral means." However, he went on to make a point which also needs to be taken into account if a sound assessment of the matter is to be made: "they are sadly divided by personal questions and jealousies: were they united there would be hope of a more vigorous policy..." 2

The rapid turn of developments in France soon put a stop to this controversy, and fully restored the basis for collaboration between Beesly and Marx.

(To be continued in the next issue).

I Congreve, R., L'Union des Prolétariats Anglais et Français, in: Essays: Political, social and religious, London 1874 , Vol. I, p. 464.

2 R. Congreve to Lobb, 14 Oct. I87o. (Congreve Papers, Wadham College, Oxford.) 